remembered, for example, that the deepest shafts at Laurion, some half a millenium earlier, were not all that short of some $400 \mathrm{ft}$.

That the enormous amount of work done in making these analyses and in collecting the data together was eminently worth whiłe no one can possibly doubt, and all those interested in ancient metals must owe the authors most grateful thanks. But there is most clearly a long, and very difficult, row still to hoe-how difficult may, perhaps, not yet have been fully realized.

F. C. Thompson

\title{
SWEDISH FORESTRY
}

$\mathrm{T}$ HE two well-known Swedish forestry publications, Meddelanden frän Statens skogsforskningsinstitut and Kungl. Skogshögskolans skrifter, are continued in a new series, Studia F'orestalia Suecica*, which began in 1963 . This series includes original papers and publication will take place at irregular intervals. Of the first nine num. bers, one has an English summary, another gives a condensed version in English and the remaining seven are in English with Swedish summaries. The range of subjects is wide. There are two accounts of resistance-biology concerning Scots pine and the twisting rust and the snow blight fungus. The second is an interesting study of the relative susceptibility to this fungus of different provenances of Scots pine in Sweden. The result of the experiments is confirmation of observations first made in 1923 that the resistance of the northern provenances is far greater than that of the southern ones except that plants from seed collected from the Arctic Ocean coast show a greater degree of susceptibility than plants from the interior of Upper Norrland. Thus the conclusion is reached that southern provenances of Scots pine should not be planted farther north but northern provenances may be introduced towards the south. Two excellent coloured plates show the difference between infected and. healthy seven-year-old Scots pine seedlings.

Another interesting mycological paper is an experimental study of the influence of temperature on the antagonistic effect of Trichoderma viride on that very important root fungus Fomes annosus. The significance of the results-not new but certainly confirmatoryis that $T$. viride is active at higher temperatures than $F$. annosus requires for growth. Thus there may be but a short period during the growing season when $T$. viride can have any appreciable effect on $\boldsymbol{F}$. annosus.

Although it is known what are the relative amounts of water-soluble substances occurring in litter from various

* Skogshögskolan, Stockholin. Studia Forestalia Suecica. Nr. 1: Preparering av Virkesavlägg pả Is. By Av Bengt Ager. Pp. $227.15 \mathrm{kr}$. Nr. 2 Studies on the Germination in Seeds of Scots Pine (Pinus silvestris L.), with Special Reference to the Light Factor. By Bengt Nyman. Pp. 164. $12 \mathrm{kr}$. Nr. 3: Leaching and Decomposition of Water-Soluble Organic Substances from Different Types of Leaf and Needle Litter. By Nils Nykvist. Pp. 31 . $3 \mathrm{kr}$ Nr. 4: The Influence of Temperature on the Antagonistic Effect of Trichoderma viride Fr. on Fomes annosug (Fr.) Cke. By Arne Persson-Huppel. Pp. 13. 2 kr. Nr. 5: Resistance of Snow Blight (Phacidium infestans Karst.) in 2 plates. $3 \mathrm{kr}$. Nr. 6: Melampsora Pinitorqua (Braun) Rostr. $\rightarrow$ Pine Twist ing Rust: "Some Experiments in Resistance-biology. By Allan Klingstrom Pp. 23. 3 kr. Nr. 7: Enzymatic Splitting of Sucrose by Some Strains of Valsa nivea Fr. By Arne Persson-Huppel. Pp. 29. 3 kr. Nr. 8: Determ ination of Mechanical Damage on Scots Pine Seed with $X$-ray Contrast Method. By S. K. Kamra. Pp. 20. (2 plates.) 2 kr. Nr. 9: Om Kostnads/Intäkts Analys Inom Skogliga Företag. By Av Karl Viktor Algvere. Pp. 169. $15 \mathrm{kr}$ (Stockholm: Svenska Skogsvardsforeninger, Box 16316, 1963.) tree species, much less is known about the factor's which influence the leaching of these substances. In a wellwritten paper, the author describes a comparison between seven different leaf and needle litters, and some very interesting results emerge. The total amount leached in a single day when expressed as a percentage of the dry weight of the litter ranges from 25 per cent in ash to 8 per cent in beech. Water-soluble substances are easily leached from leaf litter, especially alder, ash and birch, and slowly from pine and spruce litter. Temperature influences the rate of leaching in some species more than in others, and the amount of water-soluble substances is greater when leaching takes place under anaerobic rather than aerobic conditions. The author also describes the constituents of the water-soluble substances. 'This is a very useful contribution to an important subject.

In recent years, more and more attention has been directed to forest economics. Why this is so is described in a dissertation (No. 9) which considers managerial-economics (cost-revenue analysis), the objectives of the forest enterprise and its management planning. The present-day profitableness of forestry is conditioned by progressive mechanization which is itself a result of the decrease in the supply of man-power and a rise in wages and, in some: cases, to falling timber prices. Because some of the traditional methods of calculation in forest economics are based on out-dated theories, it is therefore essential that the subject must be revaluated and adjusted to those principles which are adopted in general economics. In his final chapter "Management Planning of the Forest Enterprise" K. V. Algrere shows in a most able and succinct manner that, until now, management plans have been rather rigid and he suggests that they should be regarded primarily as an instrument for revenue planning and as a basis for cost planning. The author rightly considers that planning must include establishing the justifiable density of the road network and trying to set certain standards for it. In fact, what he calls "Budgeting as a means of forestry planning" is really a case of tracing the consequences of the different possible courses of action as a result of expressing the planned activities of the enterprise in terms of costs and revenues, which are expected to occur during the planning period. By this means budgeting deals with the enterprise as a whole and thus effects a proper co-ordination of the various components into a joint programme.

C. J. TAYLOR

\section{SPECTRA AND REACTIONS IN HYDROGEN-OXYGEN-NITROGEN FLAMES WITH ADDITION OF CYANOGEN AND NITRIC OXIDE}

\author{
By P. M. RENTZEPIS* and DR. T. M. SUGDEN, F.R.S. ${ }^{\dagger}$ \\ Department of Physical Chemistry, University of Cambridge
}

$\mathrm{I}_{\mathrm{o}}^{\mathrm{N}}$ the course of a programme of work on the combustion of small amounts of various substances under the controlled conditions of a premixed hydrogen-oxygen-

* Present address: Bcll Telephone Laboratories, Inc., Murray Hill, New Jersey. † Present address: 'Shell' Research, Itd., Thornton Research Centre,
P.O. Box 1, Chester, England. nitrogen flame at atmospheric pressure we have observed the spectra produced by quantities of about 1 per cent of cyanogen, with and without a further about 1 per cent of nitric oxide in such a flame.

Tho characteristic emission spectra of the species $\mathrm{CN}$, NO, NH, CH and OH were observed photographically 